\title{
A karyotype study on the pseudoscorpion families Geogarypidae, Garypinidae and Olpiidae (Arachnida: Pseudoscorpiones)
}

\author{
FRANTIŠEK ŠŤÁHLAVSKÝ ${ }^{1,2}$, JiŘí KRÁL 2 , MARK S. HARVEY³ and CHARLES R. HADDAD ${ }^{4}$ \\ ${ }^{1}$ Department of Zoology, Faculty of Sciences, Charles University, Viničná 7, CZ-128 44 Prague 2, Czech Republic; \\ e-mail: stahlf@natur.cuni.cz \\ ${ }^{2}$ Laboratory of Arachnid Cytogenetics, Department of Genetics and Microbiology, Faculty of Sciences, Charles University, \\ Viničná 5, CZ-128 44 Prague 2, Czech Republic; e-mail: spider@natur.cuni.cz \\ ${ }^{3}$ Western Australian Museum, Locked Bag 49, Welshpool DC, Western Australia 6986, Australia; \\ e-mail: mark.harvey@museum.wa.gov.au \\ ${ }^{4}$ Department of Zoology and Entomology, University of the Free State, P.O. Box 339, Bloemfontein 9300, South Africa; \\ e-mail: haddadcr.sci@mail.uovs.ac.za
}

Key words. Pseudoscorpiones, Geogarypidae, Garypinidae, Olpiidae, karyotype, sex chromosomes, meiosis, chiasma frequency

\begin{abstract}
The karyotypes of pseudoscorpions of three families, Geogarypidae, Garypinidae and Olpiidae (Arachnida: Pseudoscorpiones), were studied for the first time. Three species of the genus Geogarypus from the family Geogarypidae and 10 species belonging to 8 genera from the family Olpiidae were studied. In the genus Geogarypus the diploid chromosome numbers of males range from 15 to 23. In the family Olpiidae the male chromosome numbers vary greatly, from 7 to 23 . The male karyotype of single studied member of the family Garypinidae, Garypinus dimidiatus, is composed of 33 chromosomes. It is proposed that the karyotype evolution of the families Geogarypidae and Olpiidae was characterised by a substantial decrease of chromosome numbers. The diploid numbers of some olpiids are the lowest known 2n within pseudoscorpions and even one of the lowest within the class Arachnida. In spite of a considerable reduction of diploid numbers, all species studied possess a X0 sex chromosome system that is widespread and probably ancestral in pseudoscorpions. Moreover, X chromosomes retain conservative metacentric morphology in the majority of species. During the first meiotic division of males, a high number of chiasmata were observed in some species, up to five per bivalent in Indolpium sp. The transient stage between pachytene and diplotene is typically characterised by extensive decondensation of chromatin in males of geogarypids and in Calocheiridius libanoticus, and we interpret this as a diffuse stage. This is recorded in pseudoscorpions for the first time. The relationships between some species belonging to the family Olpiidae are discussed based on the data obtained.
\end{abstract}

\section{INTRODUCTION}

The Class Arachnida forms a huge and archaic branch of the arthropods. Starting from the Middle Devonian almost all recent orders of arachnids have been found to be well differentiated (Selden et al., 1991). Despite the importance of arachnids, their cytogenetic systems are still poorly understood in comparison to other arthropods, especially insects. Moreover, most data were obtained from certain arachnid orders (spiders, mites, harvestmen, and scorpions) only, while other groups remain poorly understood or even untested (Král, 1994).

The order Pseudoscorpiones is the fourth largest order of arachnids and is divided into 25 families with more than 3200 described species (Harvey, 2002; Judson, 2005). From a karyological point of view, it remains a poorly investigated group. Karyotypes of only 25 species belonging to four families have been published to date. Basic information on gametogenesis and chromosomes of pseudoscorpions were presented by Sokolow (1926) in Neobisium carcinoides (Neobisiidae) and Dendrochernes cyrneus (Chernetidae), and by Boissin \& Manier (1966) in Hysterochelifer meridianus (Cheliferidae). However, only recently has the cytogenetics of pseudoscorpions been studied more intensively. Basic descriptions of the chromosome numbers and their morphology were performed in five representatives of the family Chernetidae (Št'áhlavský, 2000; Št’áhlavský et al., 2005), and two Allochthonius species (Chthoniidae) (Lee \& Seo, 1995). Karyotype evolution was analysed for the first time by Troiano (1990, 1997), who studied six Italian species of the genus Roncus (Neobisiidae). A similar study was also conducted by Št’áhlavský \& Král (2004), who investigated the karyotypes of nine European representatives of the family Chthoniidae. The data obtained were used to reconstruct the evolutionary relationships of the species studied. In both groups the evolution of karyotypes was characterised by a reduction of chromosome numbers. In the genus Roncus the main chromosome rearrangements are probably centric fusions (Troiano, 1997), while study of the genus Chthonius indicates operation of centric fusions, tandem fusions, and pericentric inversions in the evolution of the genus (Št'áhlavský \& Král, 2004). In some lineages of Mediterranean chthoniids, multiple fusions led to the origin of conspicuous "macrochromosomes" (Št'áhlavský \& Král, 2004).

From all of the above-mentioned studies it is obvious that sex chromosomes are well differentiated in pseudoscorpions. The most common type of sex chromosome determination is the system $\mathrm{X} 0$, which is probably ances- 
tral in pseudoscorpions (Troiano, 1997; Št’áhlavský \& Král, 2004). Another characteristic of pseudoscorpion karyotypes is the wide range in diploid chromosomes numbers, from $2 \mathrm{n}=10$ in Allochthonius buanensis (Chthoniidae) (Lee \& Seo, 1995) to $2 \mathrm{n}=74$ in Lasiochernes cretonatus (Chernetidae) (Št'áhlavský et al., 2005).

To supplement knowledge about the trends in karyotype evolution of pseudoscorpions, we concentrated the present study on three unstudied families, Geogarypidae, Garypinidae and Olpiidae. These groups are mainly tropical and subtropical in distribution but some species extend into temperate zones of the world. They belong to the microorder Mestommatina together with another five families characterised by the presence of long arolia (Harvey, 1992), which is a synapomorphy for this group even though considerable homoplasy occurs within the microorder. The Mestommatina is divided into two groups: the superfamily Garypoidea and the superfamily Olpioidea. The family Geogarypidae (superfamily Garypoidea) is a relatively small group that contains only 3 genera with 65 known species. The Garypinidae (superfamily Olpioidea) were recently separated from the Olpiidae by Judson (2005), who noted sufficient differences from many of the olpiids to warrant family-level recognition. The Garypinidae contains 20 genera and 74 species. The family Olpiidae (superfamily Olpioidea) contains 22 genera and 193 species (Harvey, 1991).

\section{MATERIAL AND METHODS}

Pseudoscorpions were sifted from leaf litter or collected individually from under stones or the bark of trees. Unless otherwise indicated, specimens were collected, determined, and deposited in the first author's collection (Department of Zoology, Charles University, Prague). Material from Western Australia and some specimens from South Africa are deposited in the Western Australian Museum in Perth, Australia (WAM). The detailed collection data are presented below. Species are ordered in the text, tables and figures from the highest to the lowest number of chromosomes within the families.

\section{Geogarypidae}

Geogarypus sp.: South Africa: KwaZulu-Natal, Ndumo Game Reserve (9ô, 4 ९ : 6.-10.ii.2005).

Geogarypus nigrimanus (E. Simon, 1879): Greece: Corfu Agios Georgios (6ㅇ, 1 male tritonymph: 8.iv.2004), Ágrafi (1 ठิ: 8.v.2002), Antiniotisa lake (1@̣: 16.iv.2004), Kassiopi (3 + : 24.iv.2001), lake Corission (1 $\delta:$ 23.iv.2001), Loutses (2 $\delta$ : 15.iv.2004), Paleokastrica (2 0,19 : 9.iv.2004).

Geogarypus taylori Harvey, 1986: Western Australia: John Forrest National Park, under bark of Eucalyptus sp. (40, 4 ㅇ, 1 tritonymph: 20.viii.2003), lgt. M. Štambergová and F. Št'áhlavský, det. M. Harvey, coll. WAM.

\section{Garypinidae}

Garypinus dimidiatus (L. Koch, 1873): Greece: Corfu -

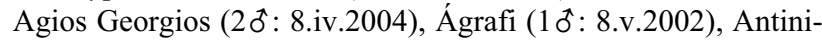

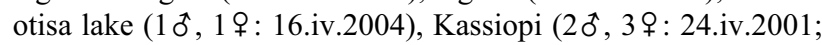
1 ô,1 $q$ : 8.v.2002), lake Corission (2 + : 23.iv.2001), Loutses (1 $9:$ 15.iv.2004)

\section{Olpiidae}

Nanolpium sp.: South Africa: KwaZulu-Natal: Ndumo Game Reserve (4ठี : 6.-10.ii.2005), lgt. D. Kunz, det. M. Harvey, coll. WAM.

Horus obscurus (Tullgren, 1907): South Africa: Soetdoring

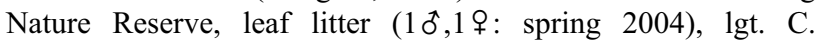
Haddad, det. M. Harvey, coll. WAM.

Calocheirus atopos (Chamberlin, 1930): Israel: Hatzeva (1 0 : 12.iii.2001), lgt. S. Pekár; Sde Boker (3ठ : 26.iv.2001), lgt. S. Pekár, (1 ठิ,1 + : 20.iv.2004), lgt. M. Řezáč.

Austrohorus sp. 1: Western Australia: Karijini National Park, (1 0,1 \% : 9.ix.2003), det. M. Harvey, coll. WAM.

Austrohorus sp. 2: Western Australia: Kalbarri National Park - the Loop, under stones (2 ô: 2.ix.2003), lgt. M. Štambergová, det. M. Harvey, coll. WAM.

Minniza babylonica Beier, 1929: Israel: Sde Boker (40ิ,1우 30.iii.-26.iv.2001), lgt. S. Pekár, det. V. Mahnert.

Calocheiridius libanoticus Beier, 1955: Turkey - Huzurkent (8 km from Tarsus) (1 đ̃: 20.iv.2002), lgt. J. Skuhrovec, det. V. Mahnert.

Olpium turcicum Beier, 1949: Israel: Sde Boker, Haluquim Ridge (3 đ: 1.-10.xii.2004), lgt. J. Král, det. V. Mahnert.

Olpium pallipes (Lucas, 1849): Greece: Corfu - lake Corission (1q: 23.iv.2001; 1 t, 5 q : 7.v.2002; $2 \widehat{0}, 6 q$ : 13.iv.2004); Portugal: Algarve, Aljezur, Praia da Bordeira near Lagos, cliffs and sand dunes (2@: 12.iv.2005), lgt. M. Řezáč, det. V. Mahnert.

Indolpium sp.: Western Australia: Kalbarri National Park, the Loop, under stones (1 ठ̊: 2.ix.2003), lgt. M. Štambergová, det. M. Harvey, coll. WAM.

\section{Methods}

Chromosome preparations were made following the technique described in detail by Štáhlavský \& Král (2004). Briefly, the gonads or the whole content of the opisthosoma were hypotonised in $0.075 \mathrm{M} \mathrm{KCl}$ for $15 \mathrm{~min}$ in geogarypids, and for $10 \mathrm{~min}$ in olpiids and garypinids. The tissues were then fixed in a glacial acetic acid : methanol $(1: 3)$ solution for at least $20 \mathrm{~min}$. After fixation a suspension was prepared in a drop of $60 \%$ acetic acid on a microscope slide. The preparation was then displaced on a warm histological plate (temperature $40-45^{\circ} \mathrm{C}$ ); the drop of suspension was moved on the surface of the slide by tungsten needle until the drop had evaporated. Chromosome preparations were stained with 5\% Giemsa solution in Sörensen phosphate buffer $(\mathrm{pH}=6.8)$ for $30 \mathrm{~min}$. in geogarypids, and for $20 \mathrm{~min}$ in olpiids and garypinids.

To obtain data on chromosome morphology, ten plates of a suitable stage (mitotic metaphase or metaphase II) were measured and evaluated. In Geogarypus sp., the centromeric area was marked by a prominent knob during diplotene, which enabled us to identify the centromere and also use these plates for the evaluation of chromosome morphology. Relative chromosome lengths (Tables 1,2$)$ were calculated as a percentage of the total chromosome length of the haploid set (TCL), including the sex chromosome. Chromosome morphology was classified according to Levan et al. (1964). In species where a sufficient number of diplotene or diakinesis was obtained, the mean chiasma frequency was calculated per cell and per bivalent (Table 3). The mean chiasma frequency per bivalent was calculated as the ratio between the mean chiasma frequency per cell and number of bivalents. In olpiids with $2 \mathrm{n}=7$, mean values of relative chromosome lengths ( $\% \mathrm{TCL})$ as well as arm ratio of corresponding autosome pairs and $\mathrm{X}$ chromosome was compared by nonparametric Mann-Whitney U Test (Table 4). 
Table 1. Genus Geogarypus. Chromosome relative lengths (\% TCL) and centromeric indexes (AR) of species studied (mit mitotic metaphase, met II - metaphase II, dip - diplotene).

\begin{tabular}{|c|c|c|c|c|c|c|c|c|c|c|}
\hline \multirow{3}{*}{$\begin{array}{l}\text { Pair } \\
\text { No. }\end{array}$} & \multirow{2}{*}{\multicolumn{2}{|c|}{$\begin{array}{c}\text { Geogarypus sp. } \\
\text { male }- \text { dip } \\
\end{array}$}} & \multicolumn{4}{|c|}{ G. nigrimanus } & \multicolumn{4}{|c|}{ G. taylori } \\
\hline & & & \multicolumn{2}{|c|}{ male - met II } & \multicolumn{2}{|c|}{ female - mit } & \multicolumn{2}{|c|}{ male - met II } & \multicolumn{2}{|c|}{ female - mit } \\
\hline & $\%$ TCL & $\mathrm{AR}$ & $\%$ TCL & $\mathrm{AR}$ & $\%$ TCL & $\mathrm{AR}$ & $\%$ TCL & $\mathrm{AR}$ & $\%$ TCL & $\mathrm{AR}$ \\
\hline 1 & 10.60 & 1.30 & 13.44 & 2.66 & 14.95 & 2.56 & 17.44 & 1.17 & 22.25 & 1.15 \\
\hline 2 & 9.74 & 1.65 & 11.15 & 1.24 & 11.87 & 1.11 & 13.06 & 1.15 & 15.08 & 1.16 \\
\hline 3 & 9.17 & 1.27 & 10.59 & 1.49 & 11.14 & 1.25 & 12.53 & 1.27 & 11.84 & 1.18 \\
\hline 4 & 7.94 & 1.26 & 9.93 & 1.14 & 10.21 & 1.18 & 12.14 & 1.13 & 11.00 & 1.17 \\
\hline 5 & 7.59 & 1.41 & 9.08 & 1.31 & 9.33 & 1.25 & 11.58 & 1.28 & 10.49 & 1.12 \\
\hline 6 & 7.26 & 2.39 & 7.95 & 1.75 & 7.30 & 1.45 & 11.35 & 1.48 & 10.26 & 1.33 \\
\hline 7 & 7.21 & 1.26 & 7.58 & 1.27 & 7.08 & 3.74 & 9.84 & 1.21 & 9.62 & 1.17 \\
\hline 8 & 6.42 & 1.37 & 6.87 & 3.07 & 6.37 & 1.32 & & & 9.46 & 1.45 \\
\hline 9 & 6.40 & 1.73 & 6.76 & 1.55 & 5.91 & 3.83 & & & & \\
\hline 10 & 5.84 & 1.17 & & & & & & & & \\
\hline 11 & 5.82 & 1.64 & & & & & & & & \\
\hline $\mathrm{X}$ & 15.90 & 1.32 & 16.82 & 1.17 & 16.24 & 1.26 & 12.06 & 1.25 & & \\
\hline
\end{tabular}

\section{RESULTS}

\section{Geogarypidae}

\section{Geogarypus sp.}

The male chromosome complement is composed of 23 chromosomes, namely nine pairs of metacentric and two pairs of submetacentric autosomes, and metacentric $\mathrm{X}$ chromosome. Autosomes gradually decrease in size; their relative lengths range from $10.06 \%$ to $5.82 \%$ of TCL in male diplotene (Table 1). The $\mathrm{X}$ chromosome is the longest element of the karyotype (15.90\% of TCL).

Only some meiotic stages were observed. In pachytene, the $\mathrm{X}$ chromosome is characterised by prominent negative heteropycnosis (Fig. 1A). The transient stage between pachytene and diplotene is marked by highly despiralised chromatin of chromosomes, with the exception of the centromere areas as well the $\mathrm{X}$ chromosome (Fig. 1B). In contrast to the transient stage, only the large proximal part of the short arm of $\mathrm{X}$ remains positively heteropycnotic during diplotene (Fig. 1C). This heteropycnotic segment forms up to $53.89 \%$ of the arm (mean $\pm \mathrm{SD}=$ $49.08 \% \pm 4.8, \mathrm{~N}=5$ ). During this stage, the centromeric regions still formed prominent knobs; two to four ring bivalents were observed. The mean chiasma frequency is 14.00 per cell or 1.27 per bivalent, respectively (Table 3 ).

\section{Geogarypus nigrimanus}

The male karyotype comprises 19 chromosomes; the sex chromosome system is X0 (Fig. 2A). Male metaphase II shows 6 metacentric, 2 submetacentric and 1 subtelocentric autosomes. The length of the chromosome pairs gradually decreases in size from $13.44 \%$ to $6.76 \%$ of TCL (Table 1). In the mitotic metaphase of females, we found slight differences in the distribution of chromosome types. It contains only 1 submetacentric but 2 subtelocentric pairs of chromosomes. This difference is probably caused by different spiralisation of some chromosome pairs in the mitotic metaphase. The metacentric chromosome $\mathrm{X}$ is the largest chromosome in the karyotype, and thus, it can also be easily recognised in the mitotic meta- phase of females (Fig. 2C). It forms $16.82 \%$ of TCL in metaphase II of males and $16.24 \%$ of TCL in female mitotic metaphase, respectively (Table 1).

We succeeded to investigate nearly the entire course of meiosis in this species. During the beginning of prophase I (leptotene and zygotene), the sex chromosome exhibits conspicuous positive heteropycnosis (Fig. 1D). In contrast to previous species, all chromosomes are isopycnotic in the pachytene (Fig. 1E). The transient stage between pachytene and diplotene is characterised by highly despiralised chromatin, with exception of the centromere areas as well as part of the $\mathrm{X}$ chromosome. The centromere areas are marked by a prominent knob and the proximal part of one $\mathrm{X}$ chromosome arm displays positive heteropycnosis (Fig. 1F). During diplotene and diakinesis, all chromosomes are isopycnotic. From metaphase II, the $\mathrm{X}$ chromosome starts to be positively heteropycnotic once again $($ Fig. $1 \mathrm{H})$. This period of heteropycnosis culminates during following anaphase II (Fig. 1I).

Males of $G$. nigrimanus exhibit a higher chiasma frequency than the previous species during late prophase I. Only one bivalent has a single chiasma whereas all other bivalents usually possess two or even three chiasmata (Fig. 1G). The mean chiasma frequency is 16.87 per cell or 1.87 per bivalent, respectively (Table 3 ).

\section{Geogarypus taylori}

The diploid chromosome number of males is 15 and all chromosomes are metacentric (Fig. 2B). The relative lengths of the autosomes range from $17.44 \%$ to $9.84 \%$ of TCL in male metaphase II (Table 1). The metacentric X chromosome forms $12.06 \%$ of TCL. During this stage, the $\mathrm{X}$ chromosome is extremely superspiralised and thus exhibits prominent positive heteropycnosis. The mitotic diploid complement of the female contains 16 chromosomes; all chromosomes are metacentric, as in the male (Fig. 2D). In both sexes the first autosome pair is distinctly longer than all other chromosomes (Table 1). The 

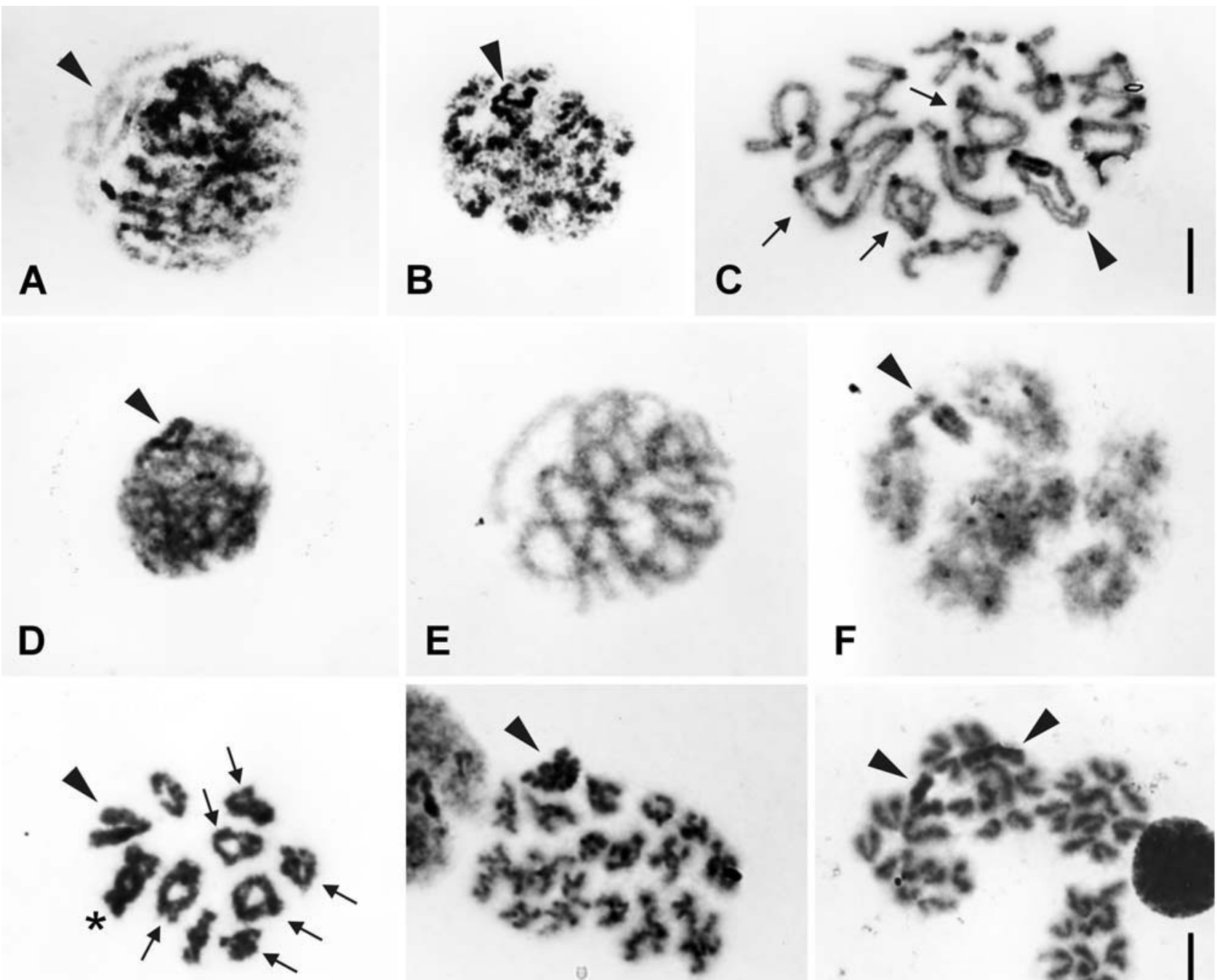

G
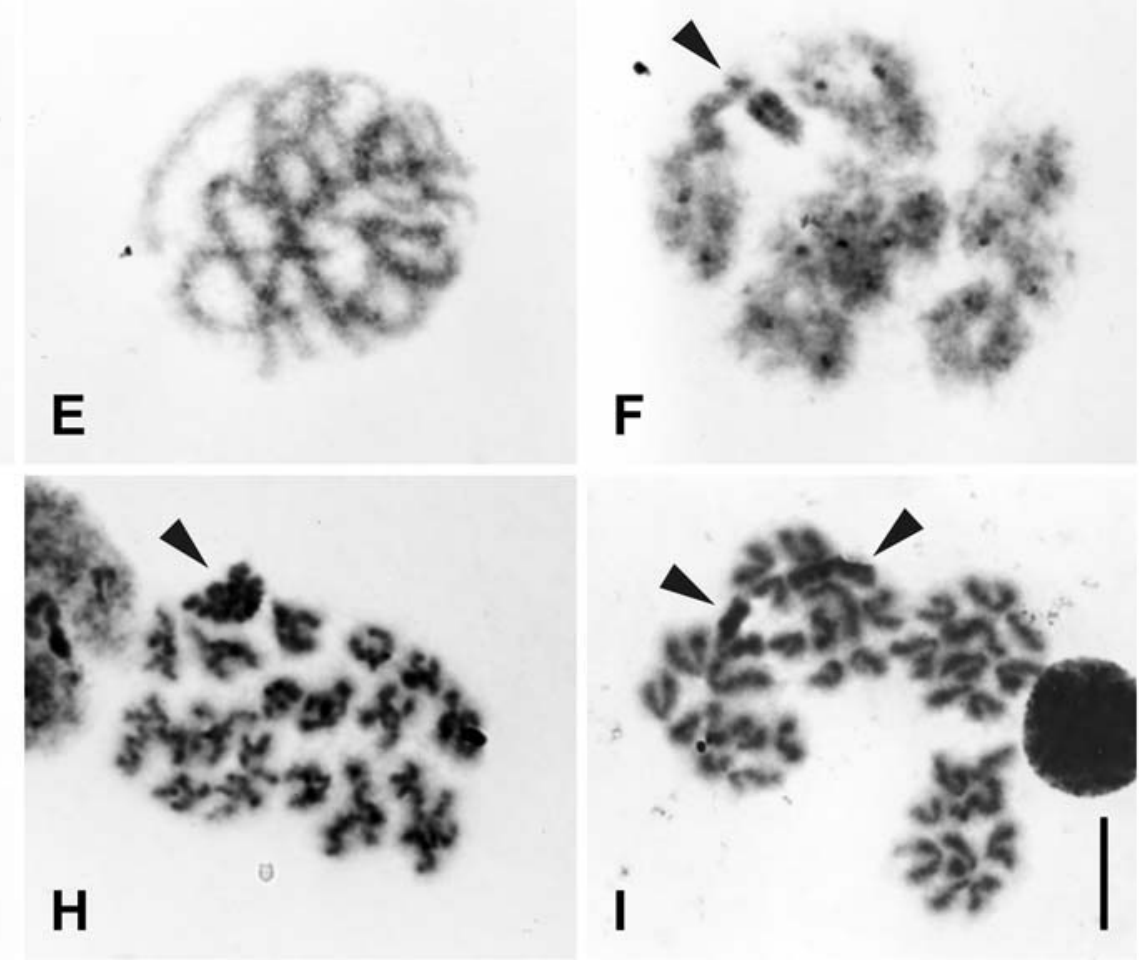

Fig. 1. Course of male meiosis in the genus Geogarypus. A - C Geogarypus sp. (South Africa). A - pachytene: sex chromosome exhibits negative heteropycnosis; $\mathrm{B}$ - diffuse stage: $\mathrm{X}$ chromosome is positively heteropycnotic; $\mathrm{C}$ - diplotene: part of sex chromosome displays positive heteropycnosis, three bivalents have two chiasmata. Scale bar $=10 \mu \mathrm{m}$ (valid for A-C). D - I Geogarypus nigrimanus. D - zygotene: sex chromosome exhibits positive heteropycnosis; $\mathrm{E}$ - pachytene: all chromosomes are isopycnotic; $\mathrm{F}$ diffuse stage: part of the sex chromosome is positively heteropycnotic; $\mathrm{G}$ - diakinesis: all chromosomes are isopycnotic, one bivalent exhibits three chiasmata (asterisk); H - metaphase II: sex chromosome displays positive heteropycnosis; I - anaphase II: sex chromosome differs by positive heteropycnosis. Scale bar $=10 \mu \mathrm{m}$ (valid for D-I). Arrowheads indicate sex chromosomes; arrows show bivalents with two chiasmata.

$\mathrm{X}$ chromosomes can therefore not be recognised based on size or morphology in the mitoses of females (Fig. 2D).

Despite the fragmentary data obtained, the course of meiotic division seems to be similar to G. nigrimanus. During leptotene and zygotene the sex chromosome exhibits positive heteropycnosis. On the other hand, all chromosomes are isopycnotic during pachytene, including the $\mathrm{X}$ chromosome. In metaphase II, the sex chromosome is newly positively heteropycnotic. Heteropycnosis during metaphase II is more prominent than in the previous species.

\section{Garypinidae}

\section{Garypinus dimidiatus}

The diploid chromosome number is 33 in males (Fig. 3A) and 34 in females (Fig. 3B). The male karyotype comprises 8 metacentric and 8 submetacentric pairs of autosomes, and one large submetacentric $\mathrm{X}$ chromosome (it forms $10.06 \%$ of TCL). The relative lengths of the autosomes decrease gradually from $8.23 \%$ in the first pair to $4.47 \%$ of TCL in pair No. 14 . The last two autosome pairs are much shorter than the preceding ones (they form $2.90 \%$ and $2.59 \%$ of TCL, respectively) (Table 2). Considering meiosis, we only observed metaphase II of males. During this stage, the $\mathrm{X}$ chromosome displays negative heteropycnosis (Fig. 6J).

\section{Olpiidae}

\section{Nanolpium sp.}

The male diploid complement contains 23 chromosomes (Fig. 3C). The male karyotype consists of three pairs of metacentric and eight pairs of acrocentric auto- 
TABLE 2. Families Garypinidae and Olpiidae. Chromosome relative lengths (\% TCL) and centromeric indexes (AR) of species studied (mit - mitotic metaphase, met II - metaphase II).

\begin{tabular}{|c|c|c|c|c|c|c|c|c|c|c|c|c|}
\hline \multirow{3}{*}{$\begin{array}{l}\text { Pair } \\
\text { No. }\end{array}$} & \multicolumn{4}{|c|}{ Garypinus dimidiatus } & \multirow{2}{*}{\multicolumn{2}{|c|}{$\begin{array}{l}\text { Nanolpium } \mathrm{sp} . \\
\text { male }- \text { met II }\end{array}$}} & \multirow{2}{*}{\multicolumn{2}{|c|}{$\begin{array}{c}\text { Horus obscurus } \\
\text { female }- \text { mit }\end{array}$}} & \multirow{2}{*}{\multicolumn{2}{|c|}{$\frac{\text { Calocheirus atopos }}{\text { male }- \text { mit }}$}} & \multirow{2}{*}{\multicolumn{2}{|c|}{$\frac{\text { Minniza babylonica }}{\text { female }- \text { mit }}$}} \\
\hline & \multicolumn{2}{|c|}{ male - met II } & \multicolumn{2}{|c|}{ female - mit } & & & & & & & & \\
\hline & $\%$ TCL & $\mathrm{AR}$ & $\%$ TCL & $\mathrm{AR}$ & $\%$ TCL & $\mathrm{AR}$ & $\%$ TCL & $\mathrm{AR}$ & $\%$ TCL & $\mathrm{AR}$ & $\%$ TCL & $\mathrm{AR}$ \\
\hline 1 & 8.23 & 1.82 & 8.34 & 2.22 & 12.19 & 1.45 & 12.68 & 1.12 & 11.26 & 1.50 & 20.13 & 1.13 \\
\hline 2 & 7.43 & 2.48 & 7.77 & 1.86 & 10.97 & 1.24 & 11.29 & 1.64 & 10.15 & 1.25 & 16.13 & 1.53 \\
\hline 3 & 7.22 & 2.16 & 7.69 & 2.60 & 9.83 & 1.28 & 9.55 & 1.43 & 9.42 & 1.17 & 16.53 & 2.17 \\
\hline 4 & 6.83 & 2.97 & 7.24 & 2.79 & 8.75 & - & 8.35 & 1.13 & 9.20 & 1.27 & 14.24 & 1.41 \\
\hline 5 & 6.62 & 2.40 & 7.04 & 1.65 & 7.83 & - & 8.28 & 1.15 & 8.87 & 1.49 & 13.74 & 1.27 \\
\hline 6 & 6.31 & 1.67 & 6.20 & 1.90 & 7.38 & - & 7.45 & 1.59 & 8.30 & 1.38 & 10.43 & 1.19 \\
\hline 7 & 5.92 & 1.62 & 5.89 & 1.68 & 7.09 & - & 7.20 & 1.24 & 7.95 & 1.29 & 9.20 & 1.20 \\
\hline 8 & 5.78 & 1.16 & 5.87 & 1.34 & 6.76 & - & 5.72 & 1.82 & 7.72 & 2.38 & & \\
\hline 9 & 5.46 & 1.70 & 5.32 & 1.13 & 6.35 & - & 5.63 & 1.23 & 6.98 & 2.45 & & \\
\hline 10 & 5.35 & 1.72 & 5.07 & 1.30 & 5.98 & - & 5.03 & 5.33 & 6.80 & 3.35 & & \\
\hline 11 & 5.11 & 1.66 & 4.98 & 1.66 & 5.54 & - & & & & & & \\
\hline 12 & 4.97 & 1.89 & 4.78 & 2.24 & & & & & & & & \\
\hline 13 & 4.74 & 1.56 & 4.71 & 1.28 & & & & & & & & \\
\hline 14 & 4.47 & 1.63 & 4.07 & 1.97 & & & & & & & & \\
\hline 15 & 2.90 & 2.20 & 3.17 & 1.53 & & & & & & & & \\
\hline 16 & 2.59 & 1.51 & 3.01 & 1.98 & & & & & & & & \\
\hline $\mathrm{X}$ & 10.06 & 1.78 & 8.93 & 1.71 & 11.33 & 1.71 & 18.82 & 1.18 & 13.36 & 1.52 & & \\
\hline \multirow{4}{*}{$\begin{array}{l}\text { Pair } \\
\text { No. }\end{array}$} & \multirow{2}{*}{\multicolumn{2}{|c|}{$\begin{array}{c}\text { Calocheiridius } \\
\text { libanoticus }\end{array}$}} & \multirow{2}{*}{\multicolumn{2}{|c|}{$\begin{array}{l}\text { Olpium } \\
\text { turcicus }\end{array}$}} & \multicolumn{6}{|c|}{ Olpium pallipes } & \multirow{2}{*}{\multicolumn{2}{|c|}{ Indolpium sp. }} \\
\hline & & & & & & Greec & Corfu & & Port & & & \\
\hline & \multicolumn{2}{|c|}{ male - mit } & \multicolumn{2}{|c|}{ male - mit } & \multicolumn{2}{|c|}{ male - mit } & \multicolumn{2}{|c|}{ female - mit } & \multicolumn{2}{|c|}{ female - mit } & \multicolumn{2}{|c|}{ male - met II } \\
\hline & $\%$ TCL & $\mathrm{AR}$ & $\%$ TCL & $\mathrm{AR}$ & $\%$ TCL & $\mathrm{AR}$ & $\%$ TCL & $\mathrm{AR}$ & $\%$ TCL & AR & $\%$ TCL & $\mathrm{AR}$ \\
\hline 1 & 19.90 & 7.83 & 35.57 & 1.10 & 35.97 & 1.36 & 39.09 & 1.58 & 40.82 & 1.38 & 36.64 & 1.27 \\
\hline 2 & 18.00 & 5.32 & 28.97 & 1.09 & 32.97 & 1.13 & 31.07 & 1.17 & 31.97 & 1.25 & 32.05 & 1.12 \\
\hline 3 & 16.50 & 8.24 & 13.15 & - & 10.88 & 1.09 & 9.61 & 1.18 & 8.47 & 1.39 & 9.05 & 3.38 \\
\hline 4 & 13.61 & 9.09 & & & & & & & & & & \\
\hline 5 & 9.40 & 1.34 & & & & & & & & & & \\
\hline$X$ & 22.58 & 1.13 & 22.23 & 1.10 & 20.19 & - & 20.33 & - & 18.73 & 1.15 & 22.26 & 1.16 \\
\hline
\end{tabular}

somes, and one large submetacentric $\mathrm{X}$ chromosome. More accurately, the $\mathrm{X}$ chromosome is metacentric in some cases (mean arm ratio $\pm \mathrm{SD}=1.71 \pm 0.16)($ Table 2). Autosomes gradually decrease in size from $12.19 \%$ to $5.54 \%$ of TCL. In meiosis, we found an enhanced chiasma frequency: three to eight of the bivalents possess two chiasmata, and one bivalent contains even three chiasmata in four cases. Mean chiasma frequency was counted as 14.40 per cell ( 1.31 per bivalent) (Table 3 ). In contrast to the other species analysed, chiasmata of ring bivalents are located more proximally, being interstitial or even pericentromeric (Fig. $6 \mathrm{H}$ ).

\section{Horus obscurus}

Data on the male karyotype are based on plates of prophase I only; diplotene consists of 10 autosome bivalents and a metacentric univalent $X$ (Fig. 6F). The female mitotic metaphase comprises 22 chromosomes (Fig. 4A). Almost all autosomes of the female are metacentric, with the exception of submetacentric pair No. 8 and subtelocentric pair No. 10. Autosomes gradually decrease in size from $12.68 \%$ to $5.03 \%$ of TCL. The female karyotype contains a pair of large metacentric $\mathrm{X}$ chromosomes that form $18.82 \%$ of TCL (Table 2 ).

At the male diplotene, the whole sex chromosome exhibits positive heteropycnosis. During this stage, quite a high number of chiasmata per cell was observed (Fig. $6 \mathrm{~F})$, ranging from 11 to 15 . Mean chiasma frequency is 12.69 per cell (1.27 per bivalent) (Table 3 ). In one case, one bivalent exhibits even three chiasmata (Fig. 6F).

\section{Calocheirus atopos}

The male mitotic metaphase includes 21 chromosomes (Fig. 4B). Autosome pairs gradually decrease in size from $11.26 \%$ to $6.80 \%$ of TCL. Metacentric chromosomes predominate in this species; seven autosome pairs are metacentric whereas only two short pairs are submetacentric (No. 8 and 9); the shortest pair is subtelocentric (Table 2). The metacentric $X$ chromosome (arm ratio 1.52) is the largest chromosome in the karyotype. It forms $13.36 \%$ of TCL (Table 2) and is thus clearly discernible in the mitotic metaphases too. Concerning meiosis, we obtained only pachytene (Fig. 6B) and diplotene (Fig. 6G) of males. In both stages the $\mathrm{X}$ chromosome exhibits promi- 


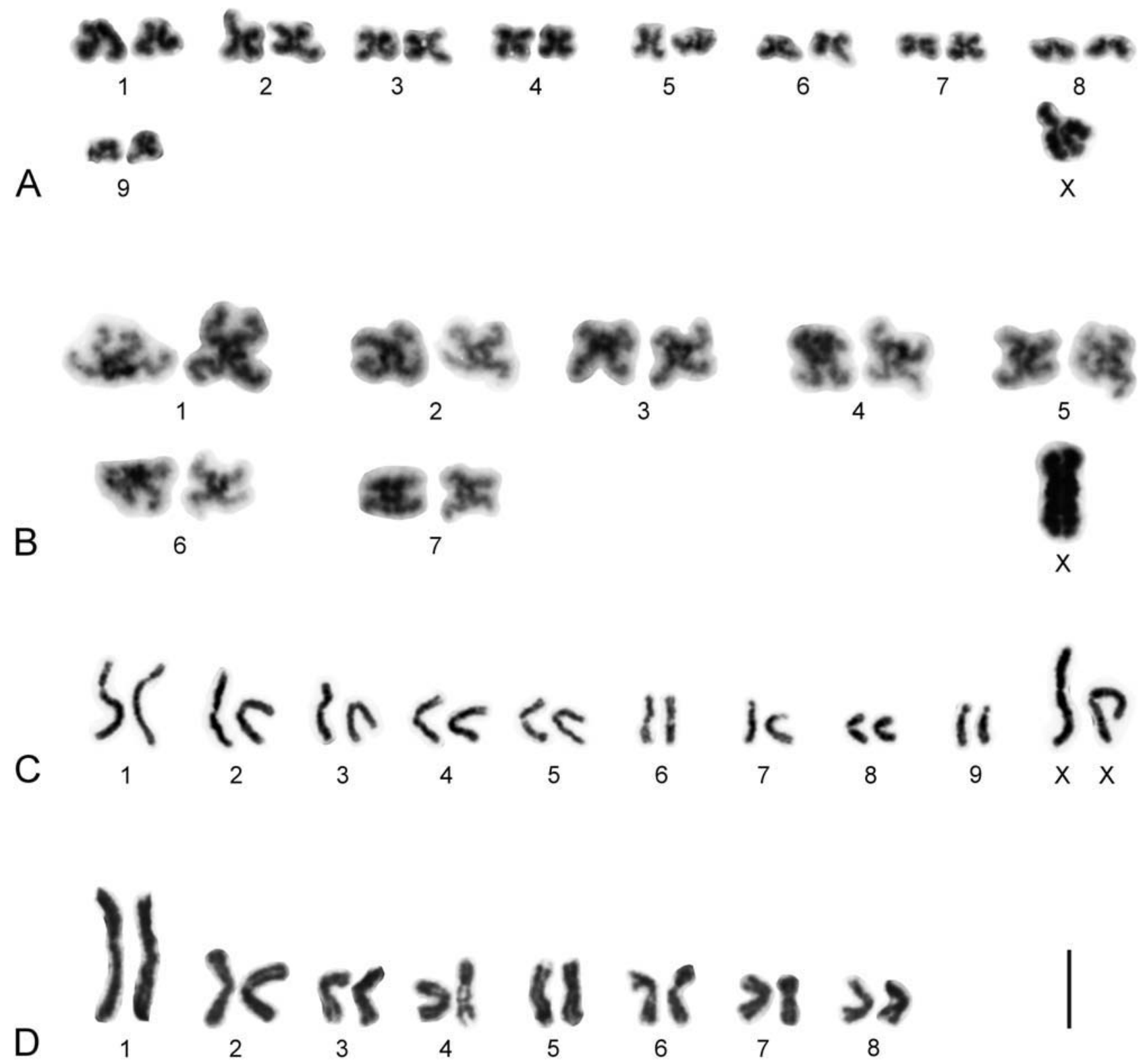

Fig. 2. A - D Karyotypes of the genus Geogarypus. A - male of G. nigrimanus, $2 \mathrm{n}=19$, X0 (assembled from 2 sister metaphase II plates); B - male of G. taylori, $2 \mathrm{n}=15, \mathrm{X} 0$ (assembled from 2 sister metaphase II plates); C - female of G. nigrimanus, $2 \mathrm{n}=20$, $\mathrm{XX}$ (mitotic metaphase); D - female of G. taylori, $2 \mathrm{n}=16, \mathrm{XX}$ (mitotic metaphase). Scale bar $=10 \mu \mathrm{m}$.

nent positive heteropycnosis. In the diplotene, ten biva- in 2-5 bivalents. Mean chiasma frequency is 12.67 per lents and a univalent $\mathrm{X}$ are visible. The majority of biva- cell (Table 3 ).

lents include one chiasma; two chiasmata were observed

TABLE 3. Mean chiasma frequency in selected species of the families Geogarypidae and Olpiidae.

\begin{tabular}{lccccc}
\hline \multirow{2}{*}{ Species } & $2 \mathrm{n}$ & No. of analysed cells & $\begin{array}{c}\text { Range of chiasma } \\
\text { frequency per cell }\end{array}$ & \multicolumn{2}{c}{ Mean chiasma frequency } \\
\hline Geogarypus sp. & 23 & 5 & $13-15$ & 14.00 & per bivalent \\
Geogarypus nigrimanus & 19 & 83 & $16-20$ & 16.87 & 1.27 \\
Nanolpium sp. & 23 & 53 & $15-19$ & 14.40 & 1.87 \\
Horus obscurus & 21 & 19 & $11-15$ & 12.69 & 1.31 \\
Calocheirus atopos & 21 & 18 & $11-14$ & 12.67 & 1.27 \\
Austrohorus sp. 1 & 19 & 15 & $9-10$ & 9.53 & 1.27 \\
Austrohorus sp. 2 & 19 & 26 & $9-11$ & 9.50 & 1.06 \\
\hline
\end{tabular}




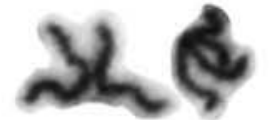

1

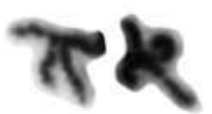

6

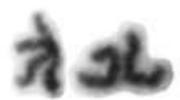

11

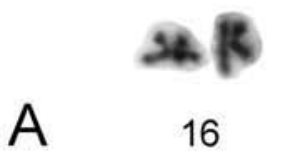

A

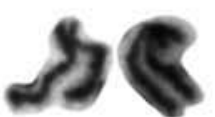

2

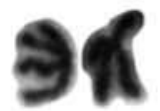

7

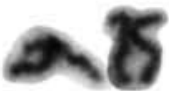

12

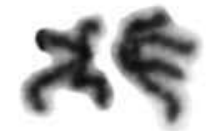

3

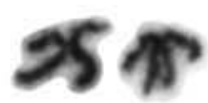

8

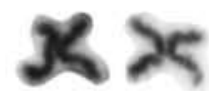

13

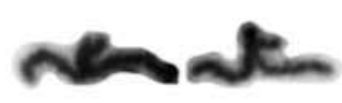

4

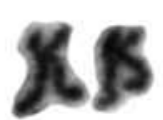

9

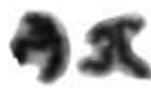

14

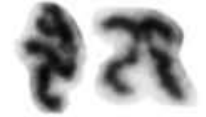

5

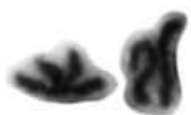

10

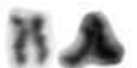

15
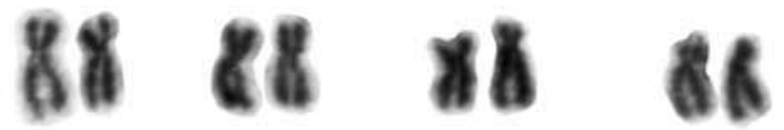

4

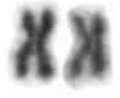

S $k$

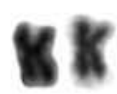

1

2

3

5

6

7

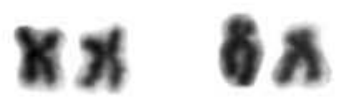

ak

ix

8 \%

$x 8$

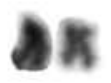

11

12

13

14

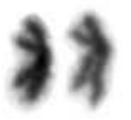

$x \times$

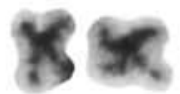

3

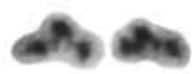

8

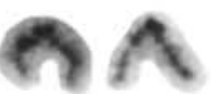

4

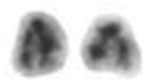

9

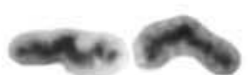

5

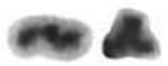

10

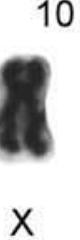

Fig. 3. A - C Karyotypes of garypinids and olpiids. A - male of Garypinus dimidiatus, $2 \mathrm{n}=33$, X0 (assembled from 2 sister metaphase II plates); B - female of G. dimidiatus, $2 \mathrm{n}=34$, XX (mitotic metaphase); C - male of Nanolpium sp., $2 \mathrm{n}=23, \mathrm{X} 0$ (assembled from 2 sister metaphase II plates). Scale bar $=10 \mu \mathrm{m}$. 


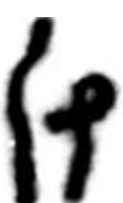

1

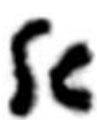

8

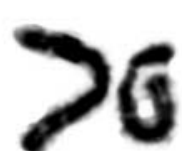

2

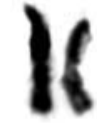

9

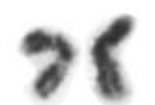

2

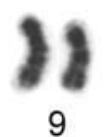

B
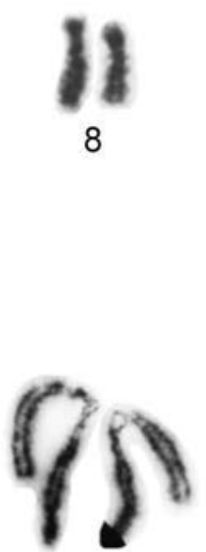

1

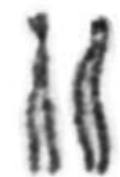

1

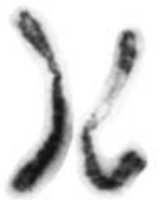

2

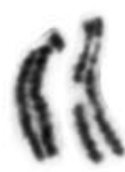

2

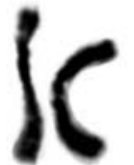

3

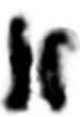

10

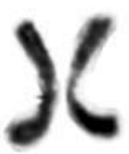

4

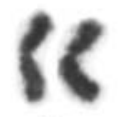

3

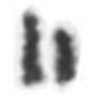

10

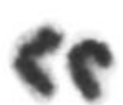

4

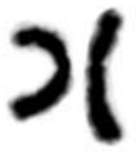

5

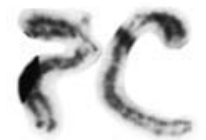

3

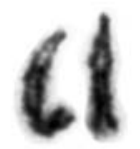

3

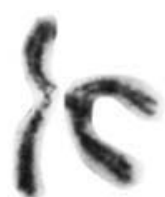

4

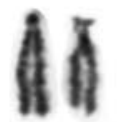

4

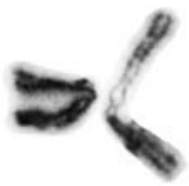

5

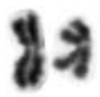

5

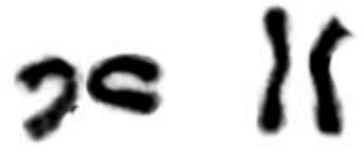

6

7
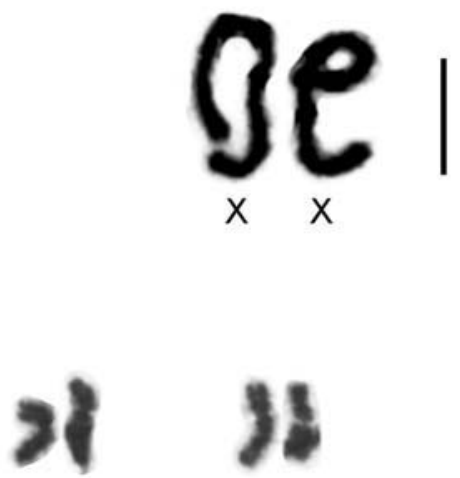

6

7

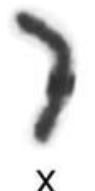

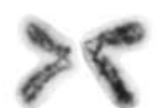

6

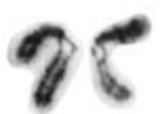

7

Fig. 4. A - D Karyotypes of olpiids constructed from mitotic metaphases. A - female of Horus obscurus, 2n = 22, XX; B - male of Calocheirus atopos, $2 \mathrm{n}=21, \mathrm{X} 0 ; \mathrm{C}-$ female of Minniza babylonica, $2 \mathrm{n}=14, \mathrm{XX} ; \mathrm{D}-$ male of Calocheiridius libanoticus, $2 \mathrm{n}=$ 11 , X0. Scale bars $=10 \mu \mathrm{m}$.

Austrohorus sp. 1 and Austrohorus sp. 2

In these two species from Western Australia we only obtained the diplotene stage. Diplotene plates of both species contain nine bivalents and one short univalent that represents the $\mathrm{X}$ chromosome (Figs 6D, 6E). In diplotene, the majority of bivalents bear one chiasma only. However, some plates contained one (Austrohorus sp. 1) or two bivalents (Austrohorus sp. 2) with two chiasmata. Chiasma frequency is nearly the same in both species.
Mean chiasma frequency is 9.53 per cell in Austrohorus sp. 1 and 9.50 in Austrohorus sp. 2 (Table 3).

\section{Minniza babylonica}

Chromosome plates were only obtained in females; mitotic metaphase consists of 14 chromosomes (Fig. 4C). Metacentric chromosomes predominate in the karyotype, and only the second pair of autosomes is submetacentric. Chromosomes gradually decrease in size from $20.13 \%$ to 


\section{A}

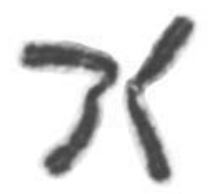

1

B

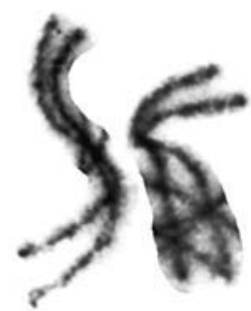

1

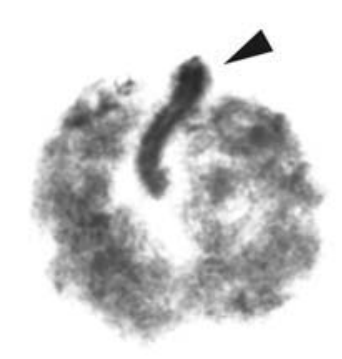

E

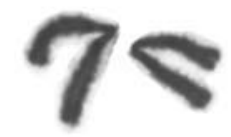

2

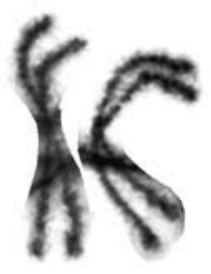

2

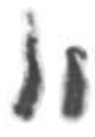

3

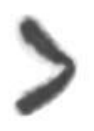

X
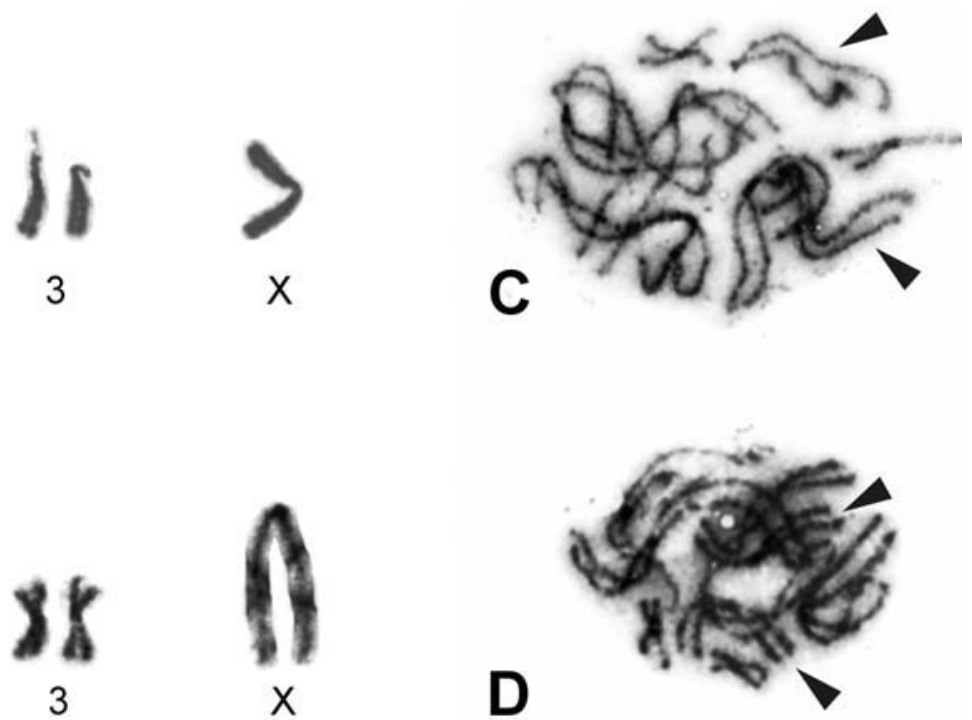

3

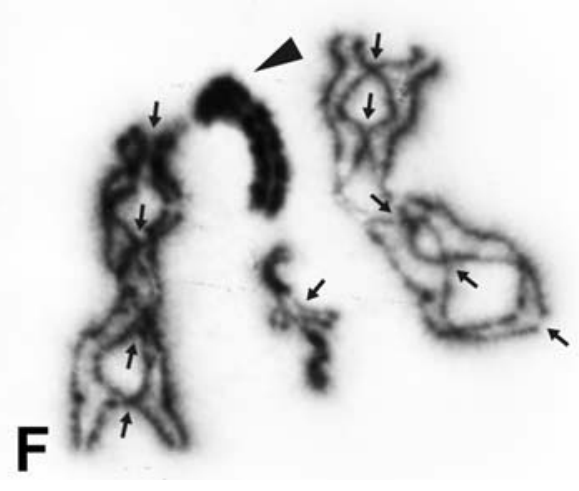

Fig. 5. A - B Karyotypes of olpiids with the lowest number of chromosomes; constructed from mitotic metaphases. A - male of Olpium turcicus, $2 \mathrm{n}=7$, X0; B - male of $O$. pallipes (Corfu), $2 \mathrm{n}=7, \mathrm{X} 0 ; \mathrm{C}$ - female mitotic metaphase of $O$. pallipes (Corfu): note acrocentric X chromosomes; D - female mitotic metaphase of $O$. pallipes (Portugal): metacentric morphology of all chromosomes indicates that X chromosomes are metacentric; E - G male meiosis of Indolpium sp., $2 \mathrm{n}=7$, X0. E - leptotene; F - diplotene: numerous chiasmata are indicated by arrows; $\mathrm{G}$ - early anaphase I. Arrowheads show sex chromosomes. Scale bar $=10 \mu \mathrm{m}$.

TABLE 4. Olpiids with $2 n=7$. Comparison of karyometric data of particular chromosome pairs by Mann-Whitney U Test. \% TCL - mean value of chromosome relative length.

\begin{tabular}{|c|c|c|c|c|c|c|c|}
\hline \multirow{2}{*}{ Compared species } & \multirow{2}{*}{$\begin{array}{l}\text { Pair } \\
\text { No. }\end{array}$} & \multicolumn{3}{|c|}{$\%$ TCL } & \multicolumn{3}{|c|}{ Arm ratio } \\
\hline & & $\mathrm{U}$ & $\mathrm{Z}$ & $p$-level & $\mathrm{U}$ & $\mathrm{Z}$ & $p$-level \\
\hline Olpium turcicus $\times$ O. pallipes & 1 & 193 & -0.98 & 0.33 & 35 & -4.75 & 0.00 \\
\hline Olpium turcicus $\times O$. pallipes & 2 & 58 & -4.20 & 0.00 & 184 & -1.19 & 0.23 \\
\hline Olpium turcicus $\times$ O. pallipes & 3 & 53 & 4.32 & 0.00 & 0 & 5.59 & 0.00 \\
\hline Olpium turcicus $\times O$. pallipes & $\mathrm{X}$ & 105 & 3.08 & 0.00 & 0 & -5.59 & 0.00 \\
\hline Olpium turcicus $\times$ Indolpium $\mathrm{sp}$. & 1 & 102 & -1.70 & 0.09 & 58 & -3.08 & 0.00 \\
\hline Olpium turcicus $\times$ Indolpium $\mathrm{sp}$. & 2 & 27 & -4.05 & 0.00 & 126 & -0.94 & 0.35 \\
\hline Olpium turcicus $\times$ Indolpium $\mathrm{sp}$. & 3 & 0 & 4.90 & 0.00 & 11 & 4.55 & 0.00 \\
\hline Olpium turcicus $\times$ Indolpium $\mathrm{sp}$. & $\mathrm{X}$ & 141 & -0.47 & 0.64 & 64 & -2.89 & 0.00 \\
\hline Olpium pallipes $\times$ Indolpium $\mathrm{sp}$. & 1 & 82 & -1.10 & 0.27 & 75 & 1.40 & 0.16 \\
\hline Olpium pallipes $\times$ Indolpium $\mathrm{sp}$. & 2 & 97 & 0.47 & 0.64 & 106 & -0.08 & 0.93 \\
\hline Olpium pallipes $\times$ Indolpium $\mathrm{sp}$. & 3 & 15 & 3.94 & 0.00 & 0 & -4.57 & 0.00 \\
\hline Olpium pallipes $\times$ Indolpium $\mathrm{sp}$. & $\mathrm{X}$ & 47 & -2.58 & 0.01 & 0 & 4.57 & 0.00 \\
\hline
\end{tabular}




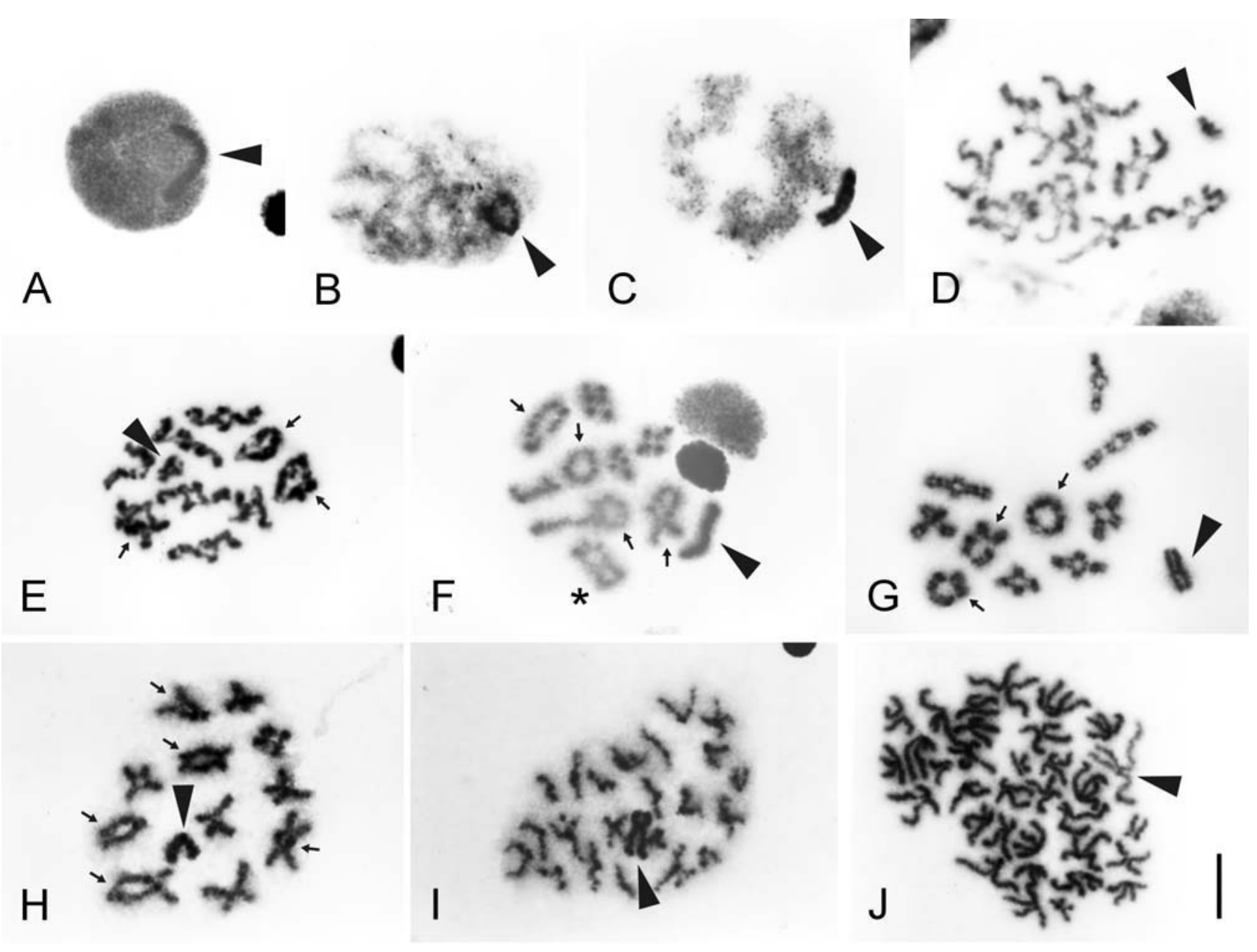

Fig. 6. A - J Course of meiosis in olpiids and garypinids. A - Horus obscurus, interphase before meiotic division: the X chromosome is positively heteropycnotic; B - Calocheirus atopos, pachytene: sex chromosome displays positive heteropycnosis; C Calocheiridius libanoticus, diffuse stage: X chromosome possesses positive heteropycnosis; D - Austrohorus sp. 1, diplotene; E Austrohorus sp. 2, diplotene; F - Horus obscurus, diplotene: note positive heteropycnosis of X chromosome, one bivalent exhibits three chiasmata (asterisk); G - Calocheirus atopos, diplotene: sex chromosome is positively heteropycnotic; $\mathrm{H}-$ Nanolpium sp., diplotene: note positive heteropycnosis of X chromosome; I - Nanolpium sp., metaphase II: X chromosome displays positive heteropycnosis; J - Garypinus dimidiatus, metaphase II: X chromosome exhibits negative heteropycnosis. Arrowheads indicate sex chromosomes; arrows show bivalents with two chiasmata. Scale bar $=10 \mu \mathrm{m}$.

$9.20 \%$ (Table 2). We were not able to distinguish sex chromosomes, neither according to size nor morphology.

\section{Calocheiridius libanoticus}

The male diploid chromosome number is 11 (Fig. 4D). In contrast to the majority of olpiid species studied, acrocentric chromosomes predominate in the karyotype of $C$. libanoticus. The autosome complement consists of three pairs of acrocentric, one pair of subtelocentric (No. 2) and one pair of metacentric chromosomes (No. 5). Autosome pairs gradually decrease in size from $19.90 \%$ to $9.40 \%$ of TCL (Table 2). The metacentric chromosome $\mathrm{X}$ is the largest chromosome of the haploid set $(22.58 \%$ of TCL). Among rare figures of male prophase I, we observed plates characterised by extensive decondensation of autosome chromatin. However, chromosome $\mathrm{X}$ is superspiralised and displays positive heteropycnosis in this stage (Fig. 6C).

\section{Olpium turcicum}

The male mitotic metaphase contains 7 chromosomes only (Fig. 5A). Chromosome pairs No. 1 and 2 are large metacentrics; they form nearly two thirds (64.53\%) of TCL. In contrast to this, pair No. 3 is acrocentric and only occupies $13.15 \%$ of TCL (Table 2). Chromosome pair No. 1 bears a conspicuous secondary constriction at the subterminal part of the long arm. This species possesses a $\mathrm{X} 0$ sex chromosome system with a metacentric X chromosome; its relative length is $22.23 \%$ of TCL.

\section{Olpium pallipes}

The male mitotic metaphase contains 7 chromosomes (Fig. 5B). The first two autosome pairs are formed by similar metacentric chromosomes of enormous size; the length of the hypotonised autosome No. 1 is approximately $29 \mu \mathrm{m}$. The first and second autosome pairs occupy $35.97 \%$ and $32.97 \%$ of TCL, respectively. The third autosome pair is formed by shorter metacentrics; it 
forms $10.88 \%$ of TCL (length of the hypotonised chromosome No. 3 is approximately $9 \mu \mathrm{m}$ ) (Table 2). This species displays a X0 sex chromosome system. In contrast to other olpiids analysed, the $\mathrm{X}$ chromosome is acrocentric in the Corfu population (Figs 5B, 5C). In males, it forms $20.19 \%$ of TCL (Table 2); its size is around $16 \mu \mathrm{m}$ in hypotonised mitotic metaphases.

In this species, we also had the chance to obtain mitotic plates from two females of a population from Portugal. Interestingly, the mitotic metaphases are composed of metacentric chromosomes only (Fig. 5D). This finding indicates that the $\mathrm{X}$ chromosome is metacentric. The autosome pairs possess similar length and morphology to the population from Corfu (Table 2).

\section{Indolpium sp.}

The male karyotype of this species from Western Australia is only composed of 7 chromosomes (Fig. 5G), as in Olpium turcicum and $O$. pallipes. The autosome complement is very similar to $O$. pallipes from South Europe. The first two autosome pairs are formed by large metacentric chromosomes; each of them forms more than a third of TCL. The last autosome pair is represented by shorter subtelocentrics that form $9.5 \%$ of TCL (Table 2). Indolpium sp. exhibits a large metacentric sex chromosome.

Positive heteropycnosis was observed in the X chromosome from the beginning of the first meiotic division (Fig. 5E) up to the early anaphase I (Fig. 5G). During diplotene, a high number of chiasmata per bivalent was observed (Fig. 5F). Large bivalents formed by metacentric autosomes possess four to five chiasmata, with two or even three on each chromosome arm. The shorter subtelocentric autosome pair exhibits one or two chiasmata (in the latter case it forms a ring bivalent).

\section{DISCUSSION}

Pseudoscorpions are poorly characterised chromosomally. In the present study, we described the karyotypes of the microorder Mestommatina, namely representatives of the families Geogarypidae, Garypinidae and Olpiidae, for the first time. In the sole member of the family Garypinidae studied, the diploid number was quite high (male $2 n=33$ ). The families Geogarypidae and Olpiidae are typically characterised by low numbers of chromosomes. Based on results previously obtained in pseudoscorpions (Troiano, 1990, 1997; Št'áhlavský, 2000; Št'áhlavský et al., 2005), we consider the low chromosome numbers in these families to be a result of considerable reduction. In males of the genus Geogarypus (Geogarypidae), the diploid number of chromosomes ranged from 15 to 23 . In the family Olpiidae, the number of chromosomes was reduced even more dramatically. Based on the study of ten species, we found the male $2 \mathrm{n}$ to range from 7 (Olpium pallipes, O. turcicum, and Indolpium sp.) to 23 (Nanolpium sp.). This study has uncovered the lowest known number of chromosomes in pseudoscorpions, a male diploid chromosome number of seven, which is amongst the lowest ever recorded amongst arachnids. This low diploid number has only been found in Ariadna lateralis (Araneae: Segestriidae), a primitive araneomorph spider exhibiting holokinetic chromosomes (Suzuki, 1954). More reduced chromosome numbers are often discovered in some mites exhibiting haplodiploidy. In mites of the suborder Mesostigmata, the diploid number can be as low as six (Oliver, 1977). This chromosome number was also discovered in one population of the scorpion Tityus bahiensis (Buthidae), a species noted for considerable differences of chromosome numbers among different populations studied (White, 1973). In some mites of the suborder Prostigmata, diploid numbers as low as four have been reported (Norton et al., 1993).

In spite of a considerable reduction in diploid numbers, the X0 sex chromosome system is preserved in all pseudoscorpion species examined during this study. It is the most frequently occurring mode in pseudoscorpions and has been found in various disparate families. Thus it is regarded as the ancestral system in pseudoscorpions (Troiano, 1990; Št'áhlavský \& Král, 2004). The extant chromosome segment on one arm of the $\mathrm{X}$ chromosome shows prominent positive heteropycnosis in Geogarypus during prophase I. We suppose that positive heteropycnosis may reflect a predominance of constitutive heterochromatin. In contrast to all other pseudoscorpions studied so far, the $\mathrm{X}$ chromosome of $O$. pallipes from Corfu is acrocentric. We suggest that this acrocentric sex chromosome developed by a pericentric inversion from an ancestral metacentric X chromosome. This initial condition is still preserved in the population of $O$. pallipes from Portugal (Fig. 5D). Because pericentric inversions can play an important role in reproductive isolation of putative species, especially in sex chromosomes (King, 1993), we consider that the taxonomic status of these chromosome forms of $O$. pallipes to be suspect and that more than one biological species may be present. Here, we classify them as two different chromosome races. It is therefore essential to analyse the karyotypes and morphology of other populations of $O$. pallipes, especially within the distribution range of this species between Portugal and Corfu, i.e. from Spain, South France, Italy and the Balkan Peninsula, to clarify the taxonomic status of this species.

The X chromosome exhibits heteropycnosis in some meiotic stages. In the genus Geogarypus we observed interspecific differences during meiotic heteropycnosis. We assume that negative heteropycnosis of the $\mathrm{X}$ chromosome during pachytene of Geogarypus sp. might reflect the metabolic activity of the sex chromosome during that stage. The relationship between the negative heteropycnosis of the sex chromosome and its metabolic activity during the early stages of spermatogenesis has been demonstrated, for example, in some grasshoppers (Church, 1979).

During the first meiotic division of males it was possible to observe a high number of chiasmata in some species; up to five per bivalent in Indolpium sp. Despite these findings, we did not explicitly establish a relation- 
ship between the reduction of chromosome numbers and rise of chiasma frequency per bivalent (Table 3).

The transient stage between pachytene and diplotene was typically characterised by extensive decondensation of chromatin in males of geogarypids and Calocheiridius libanoticus. We interpret these plates as the so-called diffuse stage. The diffuse stage is often classified as a separate period of prophase during the first meiotic division (Benavente \& Wettstein, 1980). Until now, it was demonstrated in various animals and plants, usually between pachytene and diplotene. Increased metabolic activity of the diffuse stage is expressed by the large size of the nucleus, lack (or imperfect morphology) of the synaptonemal complex, and considerable decondensation of chromatin. This stage apparently occurs most often in females due to the need to synthesise reserve substances in developing oocytes, as in humans; the occurrence in spermatocytes is not as common (Benavente \& Wettstein, 1980). A diffuse stage is recorded in pseudoscorpions for the first time. Amongst arachnids, it has been recorded in some spiders (Suzuki, 1954; Benavente \& Wettstein, 1980), ticks (Kahn, 1964), mites of the family Acaridae (Haineman \& Hughes, 1970), and the harvestman Melanopa unicolor (Sharma \& Dutta, 1959).

Previous studies on karyotype evolution within pseudoscorpions (Troiano, 1990, 1997; Štáhlavský \& Král, 2004) have shown that the considerable diversity observable in their karyotypes is useful for cytotaxonomic studies. Results of the present study demonstrate that in the families Geogarypidae and Olpiidae the karyotype diversity also appears to be sufficient for taxonomic analyses. However, the data obtained are too fragmentary and thus do not allow us to reconstruct the karyotype evolution of both families. In spite of this, comparison of representatives from distant areas such as the Mediterranean, South Africa and Western Australia allows us to make some interesting conclusions. For example, to state the similarity of the karyotypes of Horus obscurus (South Africa) and Calocheirus atopos (Israel); karyotypes of these olpiids differ in the morphology of one chromosome pair only. Remarkable similarity was found in the karyotypes of Olpium pallipes (Mediterranean), O. turcicus (Israel) and Indolpium sp. (Western Australia). Their male karyotype consists of 7 chromosomes that exhibit similar morphology (Table 2). The chromosome complement of these species contains two large metacentric pairs and one small pair of autosomes. Apart from the fact that $O$. pallipes and Indolpium sp. belong to different genera, the similarity in size of both large autosome pairs appears to be significant, whereas in $O$. turcicus and O. pallipes it is significant for the first pair of autosomes only (MannWhitney U Test, $p$-level >0.05) (Table 4). The small autosome pair exhibits variable morphology: it is metacentric in O. pallipes, subtelocentric in Indolpium sp. and acrocentric in $O$. turcicus. The distinctive morphology of the third autosome pair can be easily explained by pericentric inversions. Št'áhlavský \& Král (2004) found that pericentric inversions were frequent in the karyotype differentiation of the genus Chthonius. Moreover, this chro- mosome rearrangement probably also operated in the evolution of the $\mathrm{X}$ chromosome in $O$. pallipes. The considerable similarities mentioned above may reflect a close relationship between these three species. To clarify the origin of the karyotypes with $2 \mathrm{n}=7$, we suggest to concentrate especially on the karyotype evolution of the genera Olpium and Calocheiridius. The autosome complement of Calocheiridius libanoticus from Turkey is composed of three pairs of acrocentric, one pair of subtelocentric and one pair of metacentric chromosomes. The karyotype with seven chromosomes in $O$. turcicus may be derived from the karyotype of Calocheiridius libanoticus by two centric fusions. However, the true direction of the evolution can only be specified by further karyotype studies and/or by an analysis of molecular phylogeny.

Lastly, we emphasise the substantial differences of the karyotype of Garypinus dimidiatus $(2 \mathrm{n}=33$, X0) from the other pseudoscorpions examined in this study. This species differs from the olpiids studied by its significantly higher chromosome number and by the unusual negative heteropycnosis of $\mathrm{X}$ chromosome during metaphase II. These differences tend to support the recognition of a separate family for Garypinus and its relatives, a status which was recently proposed by Judson (2005). However, our lack of sampling any other member of the Garypinidae mitigates against any broad, sweeping assessments of the differences observed thus far.

ACKNOWLEDGEMENTS. The first author expresses immense thanks to his mother H. Štáhlavská (Prague) for considerable financial support that allowed him to collect important material for study in Greece and Western Australia. Furthermore, he is also very grateful to T. Zeman (Vrbice, Czech Republic) and Š. Hrozinka (Prague) who allowed him to join three expeditions of the Arabská secondary school (Prague) to the Greek Island of Corfu to collect pseudoscorpions there. We are very indebted to V. Mahnert (Genève) who helped us with the determination of some species. We would also like to express our thanks to S. Pekár (Prague), D. Kunz (Frankfurt-am-Main), M. Řezáč (Prague) and M. Stambergová (Stěžery, Czech Republic) for providing some of the live material used in the present study. South African species were collected with the financial support of the National Research Foundation (Pretoria, South Africa) (GUN 2068943). Our research was also partly funded by projects of the Ministry of Education, Youth and Sports of the Czech Republic (MSM 113100003, 0021620828, and J1398113100046).

\section{REFERENCES}

Benavente R. \& Wettstein R. 1980: Ultrastructural characterization of the sex chromosomes during spermatogenesis of spiders having holocentric chromosomes and long diffuse stage. Chromosoma 77: 69-81.

BoIsSIN L. \& MANIER J.F. 1966: Spermatogenèse d'Hysterochelifer meridianus (L. Koch) (Arachnida, Pseudoscorpion, Cheliferidae). I. Étude caryologique. Bull. Soc. Zool. Fr. 91: 469-476.

ChURch K. 1979: The grasshoper X chromosome. II Negative heteropycnosis, transcription activities and compartmentation during spermatogonial stages. Chromosoma 71: 359-370.

Haineman R.Z. \& Hughes R.D. 1970: Reproduction, reproductive organs and meiosis in the bisexual non-parthenogenetic 
mite Caloglyphus mycophagus, with reference to oocyte degeneration in virgins. J. Morphol. 130: 93-102.

Harvey M.S. 1991: Catalogue of the Pseudoscorpionida. Manchester Univ. Press, Manchester, New York, 726 pp.

HaRveY M.S. 1992: The phylogeny and classification of the Pseudoscorpionida (Chelicerata: Arachnida). Invertebr. Taxon. 6: 1373-1435.

Harvey M.S. 2002: The neglected cousins: what do we know about the smaller arachnid orders? J. Arachnol. 30: 357-372.

Judson M.L.I. 1992: African Chelonethi: Studies on the Systematic, Biogeography and Natural History of African Pseudoscorpions (Arachnida). Ph.D. thesis, Leeds University, 248 pp.

Judson M.L.I. 2005: Baltic amber fossil of Garypinus electri Beier provides first evidence of phoresy in the pseudoscorpion family Garypinidae (Arachnida: Chelonethi). In Logunov D.V. \& Penney D. (eds): Proceedings of the 21st European Colloquium of Arachnology, St.-Petersburg, 4-9 August 2003, pp. 127-131.

Kahn J. 1964: Cytotaxonomy of ticks. Quart. J. Micr. Sci. 105 123-137.

King M. 1993: Species Evolution: The Role of Chromosome Change. Cambridge University Press, Cambridge, 335 pp.

Král J. 1994: Přehled cytogenetiky pavoukovců. [Review of arachnid cytogenetics.] Biol. Listy 59: 282-306 [in Czech, with English abstr.].

Lee W.K. \& Seo H.Y. 1995: Soil-inhabiting Pseudoscorpions of the genus Allochthonius from Korea. Kor. J. Syst. Zool. 11: 455-468.

Levan A.K., Fredga K. \& Sandberg A.A. 1964: Nomenclature for centromeric position on chromosomes. Hereditas 52: 201-220.

Norton R.A., Kethley J.B., Johnston D.E. \& O’Connor B.M 1993: Phylogenetic perspectives on genetic systems and reproductive modes of mites. In Wrensch D.L. \& Ebbert M.A. (eds): Evolution and Diversity of Sex Ratio in Insects and Mites. Chapman \& Hall, New York, pp. 8-99.
Oliver J.H. 1977: Cytogenetics of mites and ticks. Annu. Rev. Entomol. 22: 407-429.

Sharma G.P. \& Dutta G.P. 1959: On the male heterogamety in Melanopa unicolor Roewer (Opiliones - Arachnida). Res. Bull. Panjab Univ. 10: 209-213.

Selden P.A., Shear W.A. \& Bonamo P.M. 1991: A spider and other arachnids from the Devonian of New York, and reinterpretations of Devonian Araneae. Palaeontology 34: 241-281.

SoKolow I. 1926: Untersuchungen über die Spermatogenese bei Arachniden. II: Über die Spermatogenese der Pseudoscorpione. Z. Zellforsch. Mikrosk. Anat. 3: 615-681.

SuzuKi S. 1954: Cytological studies in spiders III. Studies on the chromosomes of fifty-seven species of spiders belonging to seventeen families with general considerations on chromosomal evolution. J. Sci. Hiroshima Univ. (B) 15: 23-136.

ŠŤÁHLAVSKÝ F. 2000: Štírci (Pseudoscorpiones) Prahy (ekologie, morfologie, karyologie). [Pseudoscorpions (Pseudoscorpiones) of Prague (ecology, morphology, karyology).] MSc. thesis, Charles University, Prague [in Czech].

ŠŤÁHlavskÝ F., HenderickX H. \& Král J. 2005: Karyotype study on pseudoscorpions of the genus Lasiochernes Beier (Pseudoscorpiones: Chernetidae). Folia Biol. (Kraków) 53: 69-74.

ŠŤÁHLAVSKÝ F. \& KRÁL J. 2004: Karyotype analysis and achiasmatic meiosis in pseudoscorpions of the family Chthoniidae (Arachnida: Pseudoscorpiones). Hereditas 140: 49-60.

Troiano G. 1990: Karyotype and male meiosis of four species of Roncus L. Koch, 1873 (Pseudoscorpionida, Neobisiidae). Boll. Zool. 57: 1-9.

Troiano G. 1997: Further studies on caryology of the pseudoscorpions of the gen. Roncus: the karyotype of Roncus gestroi and Roncus belluatii. Caryologia 50: 271-279.

White M.J.D. 1973: Animal Cytology and Evolution. 3rd ed. Cambridge University Press, 961 pp.

Received September 27, 2005; revised and accepted November 9, 2005 